http://dx.doi.org/10.18778/8088-839-5.02

\author{
Aleksandra Trzcielińska-Polus \\ Uniwersytet Opolski
}

\title{
25 lat polityki zjednoczonych Niemiec wobec Polski
}

Po upływie 25 lat od podpisania traktatu o dobrym sąsiedztwie i przyjaznej współpracy, obecne relacje polsko-niemieckie określane są w Polsce mianem chłodnych, znajdujących się w impasie lub „na rozdrożu”" Niemcom zarzuca się dążenie do dominacji nad Polską oraz inspirowanie działań na rzecz zdyscyplinowania, a nawet upokorzenia naszego kraju na arenie międzynarodowej (głównie w Unii Europejskiej). Historia odgrywa ponownie jedną z głównych ról w kształtowaniu polityki wobec naszego zachodniego sąsiada, a antyniemieckie fobie zyskują na znaczeniu.

W RFN opinie o stanie stosunków polsko-niemieckich są bardziej zróżnicowane: część polityków i analityków mówi o stanie „normalności”, inni natomiast - o kryzysie, stawianiu kolejnych murów, kopaniu nowych rowów, a niekiedy nawet o „zatrutej atmosferze”. W raporcie Grupy Kopernika z 21 czerwca 2016 roku konstatuje się „znaczne dystansowanie się Polski od Niemiec"2. Paradoksem można nazwać to, że właśnie w roku jubileuszu relacje Polski z zachodnim sąsiadem uległy znacznemu ochłodzeniu w porównaniu do stanu $\mathrm{z}$ ostatnich ośmiu lat.

Gdyby dokonać analizy haseł, jakich używano dla charakterystyki stosunków polsko-niemieckich, to na ich podstawie stwierdzić można zachodzące w nich wraz z upływem czasu zmiany. Na początku lat 90. politycy zarówno

1 K. Ruchniewicz, Stosunki na rozdrożu, „przez granice”, „Kurier Szczeciński” dod. „SGP Euroregionu Pomerania” 2016, nr 1, s. 12-13.

2 Komunikat Grupy Kopernika - Partnerstwo Polski i Niemiec to skarb, który należy chronić i pomnażać, http://akademia.krzyzowa.org.pl/index.php?option=com_ content\&view=article\&id=174:komunikat-nr-27-partnerstwo-polski-i-niemiecto-skarb-ktory-nalezy-chronic-i-pomnazac\&catid=10\&lang\&Itemid (dostęp: 25.06.2016). 
polscy, jak i niemieccy mówili o „wspólnocie interesów” (Interessengemeinschaft) oraz o „wspólnocie wartości” (Wertegemeinschaft)³. Tę najważniejszą wspólną wartość stanowiła bezpieczna Europa i proces jej integracji, a także sam system aksjologiczny, który legł u podstaw zjednoczenia Starego Kontynentu i zapisany został w traktatach założycielskich. Prezydent Bronisław Komorowski, występując w 2014 roku w Bundestagu, a także minister spraw zagranicznych Niemiec Frank-Walter Steinmeier, podczas kwietniowej wizyty w Polsce w 2016 roku, ze szczególnym naciskiem podkreślali polsko-niemiecką „wspólnotę odpowiedzialności” (Verantwortungsgemeinschaft). Wspólnocie interesów i wspólnej odpowiedzialności dano już wyraz w preambule traktatu o dobrym sąsiedztwie i przyjaznej współpracy w kontekście zadania „zbudowania Europy nowej, wolnej i zjednoczonej przez prawa człowieka, demokrację i idee państwa prawa"4.

W omawianym okresie bywało jednak również tak, że zarówno politycy, jak i politolodzy konstatowali w relacjach polsko-niemieckich istnienie antagonizmów, polaryzacji stanowisk, konkurencji, a także „wspólnoty konfliktów” (Konfliktgemeinschaft) i „sprzecznych interesów” (Streitgemeinschaft). Dotyczyło to w szczególności okresu, kiedy Polska przystępowała do Unii Europejskiej, a także czasu sprawowania rządów przez Prawo i Sprawiedliwość, Ligę Polskich Rodzin i Samoobronę (lata 2005-2007) oraz obecnie - po przejęciu władzy w 2015 roku przez PiS. O braku jedności poglądów mowa jest obecnie w kontekście współczesnych koncepcji relokacji migrantów w związku z trwającym od 2015 roku kryzysem uchodźczym z państw Bliskiego Wschodu i Afryki Północnej, kształtowania stosunków z Rosją (w tym kwestii utrzymania lub zniesienia sankcji wobec tego państwa) i rozwiązania konfliktu na Ukrainie, strategii bezpieczeństwa energetycznego, polityki ograniczenia emisji gazów cieplarnianych, a przede wszystkim kształtu ostatecznego (finalité) i kompetencji Unii Europejskiej.

3 W.D. Eberwein, M. Ecker-Ehrhardt, Deutschland und Polen. Eine Werte- und Interessengemeinschaft? Die Eliten-Perspektive, Opladen 2001; Stosunki polsko-niemieckie 1949-2005. Wspólnota wartości i interesów?, B. Kerski, W. D. Eberwein (red.), Olsztyn 2005.

4 Die deutsch-polnischen Verträge vom 14.11.1990 und 17.6.1991/Traktaty polsko-niemieckie z 14.11.1990 r. i 17.6.1991 r., MSZ i MSW RFN we współpracy z Ambasadą RP w Kolonii, [b.m.i r.w.], s. 21.

5 M.A. Cichocki i in., Wspólnota sprzecznych interesów? Polska i Niemcy w procesie rozszerzania Unii Europejskiej na Wschód, Warszawa 1999; D. Bingen, 25 Jahre deutsch-polnische Partnerschaft. Politische Freundschaft auf Bewährung, „Polen - Analysen" nr 180 z 19.04.2016, s. 5, 10. 
Niemieccy politycy dorobek ostatniego ćwierćwiecza w stosunkach polsko-niemieckich nazywają "historią sukcesu” (Erfolgsgeschichte) ${ }^{6}$, „darem” $\left(\right.$ Geschenk) ${ }^{7}$, „wielkim skarbem” (ein Schatz) ${ }^{8}$, który należy pielęgnować i powiększać, łutem szczęścia (Glücksfall) ${ }^{9}$, a kanclerz Angela Merkel podczas wizyty premier Beaty Szydło w Niemczech w lutym 2016 roku określiła „normalność relacji niemiecko-polskich wobec potworności zbrodni popełnionych przez Niemców w Polsce [...] małym cudem" ${ }^{10}$. W przyjętej 23 czerwca 2016 roku przez Bundestag uchwale „Pojednanie, partnerstwo, współpraca - 25-lecie niemiecko-polskiego Traktatu o dobrym sąsiedztwie i przyjaznej współpracy" podkreślono, że minione ćwierćwiecze to historia sukcesu, pojednania, partnerstwa i przyjaźni naszych narodów ${ }^{11}$.

To szerokie spektrum wartościujących określeń w odniesieniu do dwustronnych relacji Polski i RFN ukazuje z jednej strony zróżnicowane podejścia (konstatację zarówno zbieżności, jak i różnic interesów) ${ }^{12}$, a z drugiej

6 E. Stasik, Merkel: dobre relacje z Polska nie były oczywistościa, http://www.dw.com/ pl/merkel-dobre-relacje-z-polsk\%C4\%85-nie-by\%C5\%82y-oczywisto\%C5\%9Bci\% C4\% 85/a-19337772 (dostęp: 25.06.2016).

7 Szef Komisji Spraw Zagranicznych Bundestagu, Norbert Röttgen (CDU), określił tak stosunki polsko-niemieckie 22.06.2016 r. przed konsultacjami międzyrządowymi w Berlinie w wypowiedzi dla ZDF-Morgenmagazin, http://www.wochenblatt. de/nachrichten/welt/Roettgen-bezeichnet-deutsch-polnische-Beziehungen-als-Geschenk;art29,376509 (dostęp: 25.06.2016).

8 Tak nazwane zostały stosunki między naszymi państwami m.in. przez ambasadora RFN w Polsce Rolfa Nikela po rozmowie w styczniu 2016 r. z polskim ministrem spraw zagranicznych, a także przez konsul RFN w Opolu, Sabine Haake oraz rzecznika rządu RFN Steffena Seiberta. Por.: K. Ogiolda, Trzeba dbać o skarb polsko-niemieckich stosunków, „Nowa Trybuna Opolska” 29.01.2016; Niemcy: Nie planujemy sankcji przeciw Polsce. Nasze stosunki sq skarbem, http://swiat.newsweek.pl/niemcy-o-stosunkach-polsko-niemieckich-nie-planujemy-sankcji-przeciwko-polsce, artykuly,377103,1.html (dostęp: 16.04.2016); H. Jarczyk, Alles bestens? Deutsch-polnische Beziehungen, https:// www.tagesschau.de/ausland/polen-mediengesetz-129.html (dostęp: 16.04.2016).

9 D. Bingen, $d z$. cyt., s. 2.

10 K. Tokarz, Berlin obawia sie wyemancypowanej Polski, http://www.stosunki.pl/?q= content/berlin-obawia-si\%C4\%99-\%E2\%80\%9Ewyemancypowanej\%E2\%80\%9 D-polski (dostęp: 16.04.2016).

11 Deutscher Bundestag, Drucksache 18/8861 vom 21.06.2016, Antrag der Fraktionen der CDU/CSU und SPD: Versöhnung, Partnerschaft, Zusammenarbeit - 25 Jahre deutsch-polnischer Vertrag über gute Nachbarschaft und freundschaftliche Zusammenarbeit.

12 M. Stolarczyk, Zbieżność i różnice interesów w stosunkach polsko-niemieckich $w$ latach 1989-2009, Katowice 2010. 
strony, nakazuje badać opinie na temat różnych aspektów, dziedzin i płaszczyzn wzajemnych interakcji, a w konsekwencji dywersyfikację ich percepcji. Chodzi bowiem nie tylko o stosunki polityczne, ale również o gospodarcze, społeczne, kulturalne, naukowe etc. Oprócz tego zauważalne jest też zróżnicowanie regionalne opinii, gdyż dużą rolę odgrywa geograficzna bliskość sąsiada. Dwustronne interakcje są oceniane przez elity polityczne, analityków i naukowców, biznesmenów, a także na poziomie różnych grup społecznych i pojedynczych członków obu społeczeństw. Ich odczucia, opinie i oczekiwania często nie były i nie są tożsame.

Sympatia społeczeństwa polskiego do Niemców systematycznie rośnie, podczas gdy pozytywne postrzeganie Polaków przez naszych zachodnich sąsiadów uległo $\mathrm{w}$ ostatnim czasie pogorszeniu. Potwierdzają to badania prowadzone od 2000 roku przez Instytut Spraw Publicznych we współpracy z Fundacją Bertelsmanna i Fundacją Konrada Adenauera. W badaniu z kwietnia 2016 roku sympatię do Niemców wyrażało 53\% ankietowanych Polaków, którzy akceptowali Niemców we wszystkich rolach społecznych (np. sąsiada, szefa czy członka rodziny). W Niemczech natomiast wzrosła niechęć do Polaków, a poziom sympatii spadł do zaledwie 28\%. Niemcy wyrażali akceptację dla Polaków przede wszystkim w neutralnych rolach społecznych (kolega z pracy, sąsiad, mieszkaniec) ${ }^{13}$.

Ponad dwie trzecie Polaków pozytywnie oceniło w tymże badaniu stan stosunków polsko-niemieckich (67\%). Złą opinię o tych relacjach wyraziło tylko $19 \%$. Natomiast prawie połowa Niemców (45\%) uważała, że stan wzajemnych stosunków jest zły. Był to najgorszy wynik od 2000 roku. Podobny odsetek (43\%) badanych miało dobre zdanie na ten temat ${ }^{14}$. Najbardziej niepokojąco brzmi jednak opinia 56\% Niemców, iż Polska nie jest wiarygodnym partnerem w Unii Europejskiej.

Sporządzając bilans ćwierćwiecza potraktatowych stosunków warto zadać następujące pytania: Jaką pozycję zajmowała Polska w ciągu minionych 25 lat wśród innych europejskich partnerów politycznych Niemiec? Czy Rzeczpospolita była przez Niemcy traktowana jak równoprawny sojusznik (wszak oba państwa są członkami UE i NATO), czy była marginalizowana i pozostawała „partnerem drugiej kategorii”? Dla Polski bowiem od początku lat 90. XX wieku stosunki z Niemcami stanowiły bezsprzecznie jeden ze strategicznych priorytetów w polityce zagranicznej.

13 A. Łada, Barometr Polska-Niemcy 2016. Polacy i Niemcy o sobie nawzajem 25 lat po podpisaniu traktatu o dobrym sąsiedztwie i przyjaznej wspótpracy, Warszawa 2016, s. $21,33,35$.

14 Tamże, s. 41. 
Głównym aktorem w kreowaniu, koordynacji i realizacji niemieckiej polityki zagranicznej jest kanclerz. To on wytycza najważniejsze cele i zadania w polityce oraz ponosi odpowiedzialność za proces ich urzeczywistniania. Resortem odpowiadającym za kontakty z zagranicą jest w RFN Urząd Spraw Zagranicznych (Auswärtiges Amt) z ministrem spraw zagranicznych na czele. Stąd w niniejszym przyczynku główna uwaga skupiona jest na retoryce i polityce wobec Polski (Polenpolitik) realizowanej przez kanclerza i ministra spraw zagranicznych. Podkreślona zostanie jednak także rola Bundestagu jako forum współtworzenia polityki zagranicznej, albowiem to w parlamencie prezentowane i dyskutowane są założenia polityki zagranicznej oraz następuje kontrola ich wykonania. Ponadto, Bundestag był w omawianym ćwierćwieczu inicjatorem przyjmowania wielu rezolucji i uchwał dotyczących stosunków z Polską, organizatorem debat, dyskusji, spotkań i wystaw, które można traktować jako współudział w procesie konceptualizacji i realizacji polityki wobec naszego kraju. Ważnymi współkreatorami polityki, a przede wszystkim atmosfery w stosunkach polsko-niemieckich byli również prezydenci (Richard von Weizsäcker, Roman Herzog, a także urzędujący do niedawna Joachim Gauck).

Polityka Niemiec wobec Polski do czasu podpisania traktatów w 1990 i 1991 roku stanowiła integralną część polityki wschodniej (Ostpolitik) tego państwa. Po tym fakcie, a szczególnie po stowarzyszeniu Polski ze Wspólnotami, stała się częścią niemieckiej polityki europejskiej (Europapolitik), a jednym $\mathrm{z}$ jej celów była pomoc w demokratyzacji stosunków i stabilizacji sytuacji w najbliższym sąsiedztwie w dobrze pojętym własnym interesie.

Relacje polsko-niemieckie były i pozostają stosunkami asymetrycznymi, co wynika z różnicy potencjałów i odmiennego statusu obu państw na arenie międzynarodowej (głównie europejskiej). Odzwierciedleniem tej asymetrii były $\mathrm{m}$.in. role pełnione przez oba państwa $\mathrm{w}$ procesie rozszerzenia UE z 2004 roku: Niemcy odgrywały rolę adwokata, Polska natomiast - rolę klienta ${ }^{15}$. Pracownicy z Polski wyjeżdżają do pracy w Niemczech. W przeciwnym kierunku proces ten ma ograniczony charakter. Podobne dysproporcje dotyczą lokowania kapitału w formie inwestycji bezpośrednich. Asymetryczne pozostają uregulowania statusu i realizacji praw mniejszości niemieckiej w Polsce oraz Polonii w Niemczech.

Minione ćwierćwiecze było w stosunkach polsko-niemieckich (zarówno z punktu widzenia polityki Niemiec wobec Polski, jak i polityki Polski wobec Niemiec) okresem ze wszech miar niejednolitym. Bezsprzecznie były to lata

15 D. Bingen, $d z$. cyt., s. 4. 
pełne pozytywnych przemian, ale także nierozwiązanych problemów, niespełnionych oczekiwań i nowych wyzwań. W analizowanym czasie doszło do znacznego wzrostu roli i znaczenia Niemiec na arenie międzynarodowej, przede wszystkim w Europie ${ }^{16}$. Pozycja i wizerunek Polski również uległy pozytywnej zmianie. Po procesie transformacji społeczno-politycznej i gospodarczej oraz modernizacji, Polska stała się członkiem Unii Europejskiej i NATO, a więc tych samych organizacji co zjednoczone Niemcy - struktur niezmiernie ważnych ze strategicznego punktu widzenia dla zapewnienia szeroko pojętego bezpiecznego funkcjonowania naszego państwa. W okresie tym narastały bowiem zagrożenia dla bezpieczeństwa (przede wszystkim zagrożenia asymetryczne) związane z międzynarodowym terroryzmem (w tym cyberterroryzmem), skutkami kryzysu ekonomicznego i finansowego, niekontrolowanymi procesami migracyjnymi, degradacją i zanieczyszczeniem środowiska naturalnego oraz zmianami zachodzącymi na rynku surowców (głównie energetycznych).

Z jednej strony ze względu na modyfikacje celów i paradygmatów (a także metod i środków) polityki prowadzonej przez Niemcy wobec naszego państwa oraz stosowaną retorykę, a z drugiej strony z punktu widzenia recepcji tejże polityki w Polsce, podzielić należy omawiane ćwierćwiecze na trzy subokresy: 1. 1990-1998 - lata nazywane fazą porozumienia i pojednania z Polską. W kontekście tego określenia okres ten porównywany bywa często do czasów, gdy następowało pojednanie Niemiec z Francją. Dominującym działaniem rządu kanclerza Kohla (koalicji CDU/CSU-FDP) było wówczas popieranie starań Polski o stowarzyszenie, a następnie członkostwo we Wspólnotach/Unii Europejskiej oraz w NATO. Polska droga do tych struktur prowadziła przez Niemcy;

2. 1998-2007 - faza załamania lub inaczej lata dystansu. Władzę w Niemczech od 1998 do 2005 roku sprawowali socjaldemokraci wraz z partią Zielonych, a w 2005 roku powstała tzw. wielka koalicja chadeków i socjaldemokratów. Był to okres zbliżenia niemiecko-rosyjskiego i pogorszenia stosunków z Polską w związku z poparciem udzielonym przez nasz kraj Stanom Zjednoczonym odnośnie do agresji w Iraku. Impulsem do załamania polsko-niemieckich relacji było w 1998 roku przeforsowanie przez polityków związanych ze Związkiem Wypędzonych rezolucji Bundestagu „Wypędzeni, przesiedleńcy i mniejszości niemieckie są pomostem pomiędzy

16 „Zakamuflowana potęga”, „centralna siła w Europie”, „, hegemon wbrew własnej woli” - to określenia przywódczej roli Niemiec w Unii Europejskiej. Por. np.: H.P. Schwarz, Die Zentralmacht Europas. Deutschlands Rückkehr auf die Weltbühne, Berlin 1994. 
Niemcami i ich wschodnimi sąsiadami”" ${ }^{17}$, a następnie sprzeciw Polski wobec projektu budowy Centrum przeciw Wypędzeniom w Berlinie;

3. 2007-2015 - faza poprawności i dążenia do dojrzałego partnerstwa - to dwie kadencje, w których władzę w Polsce sprawowała koalicja PO-PSL, a w Niemczech trwały rządy chadeków w koalicji z SPD (2005-2009), następnie z FDP (2009-2013) i ponownie z SPD (od 2013 roku). Był to okres znacznej poprawy atmosfery wzajemnych relacji. $\mathrm{W}$ tym czasie doszło m.in. do zwołania przez wiceministra spraw wewnętrznych Christopha Bergnera obrad tzw. okrągłego stołu w sprawie wspierania niemieckiej mniejszości w Polsce i obywateli niemieckich polskiego pochodzenia oraz Polaków w Niemczech. W roku 2011 odbyły się uroczyste obchody 20. rocznicy traktatu o dobrym sąsiedztwie i przyjaznej współpracy, którym towarzyszył pozytywny bilans dwóch dekad wzajemnych stosunków oraz wytyczenie zadań do realizacji w przyszłości.

Od przejęcia władzy przez PiS w 2015 roku trwa wspomniany już okres ochłodzenia w relacjach polsko-niemieckich. Polskę i Niemcy dzieli wiele kwestii, wśród nich przede wszystkim ocena realizacji praw Polonii w Niemczech, podejście do sposobu rozwiązania kryzysu migracyjnego, zapewnienia bezpieczeństwa energetycznego Polski i całej Unii Europejskiej, w tym głównie brak zgody na forsowaną przez Niemcy budowę gazociągu Nord Stream 2. Protokół rozbieżności pozostaje obszerny. Impas, „inscenizowaną harmonię" czy „udawaną koncyliacyjność” (określenie ministra Witolda Waszczykowskiego) miały zażegnać konsultacje międzyrządowe, jakie odbyły się w dniach 22-23 czerwca 2016 roku w Berlinie. Czy jednak zażegnały, przekonamy się w najbliższych miesiącach.

Cezury podanej wyżej periodyzacji wynikają nie tylko ze zmian koalicji rządowych, ale przede wszystkim związane są z uwarunkowaniami zewnętrznymi - nowymi wyzwaniami na arenie europejskiej i międzynarodowej oraz wewnętrznymi - z kwestiami problematycznymi w stosunkach dwustronnych. Wśród głównych tematów (aspektów) podejmowanych w mediach, publikacjach naukowych i enuncjacjach polityków w kontekście relacji polsko-niemieckich na miejscu pierwszym znajdowała się historia, na drugim polityka europejska, na trzecim zaś - kwestie gospodarcze. Uznać je więc należy za najważniejsze determinanty dwustronnych stosunków.

17 Deutscher Bundestag, Drucksache 13/108845 vom 27.05.1998, Antrag der Fraktionen der CDU/CSU und FDP: Vertriebene, Aussiedler und deutsche Minderheiten sind eine Brücke zwischen den Deutschen und ihren östlichen Nachbarn. 
ad 1/ Lata 1990-1998 to pierwszy okres. Określany jest on powszechnie jako czas, w którym dominującą motywacją w polityce Niemiec wobec Polski było doprowadzenie do zbliżenia, porozumienia i pojednania z Polakami. Po latach konfrontacji, gdy wiele nieuregulowanych kwestii (przede wszystkim potwierdzenie granicy na Odrze i Nysie Łużyckiej oraz uznanie mniejszości niemieckiej w Polsce i realizacja jej praw) było przyczyną napięć i problemów, opinie formułowane w odniesieniu do relacji polsko-niemieckich w początkowych latach 90 . XX wieku wyrażały jednoznaczną aprobatę i pozytywny stosunek do zachodzących zmian: „nowa (czyli: lepsza) jakość”, „zwrot”, „przełom”, „nowy etap/rozdział”.

Hans-Adolf Jacobsen był zdania, że po przełomowym 1989 roku, Polska i Niemcy przeszły od fazy funkcjonowania obok siebie do fazy współdziałania $^{18}$, a Anna Wolff-Powęska mówiła o fazie idealizmu towarzyszącej procesowi poprawy stosunków polsko-niemieckich i demokratyzacji Rzeczypospolitej $^{19}$.

Cezurę stanowiła normalizacja stosunków, tj. podpisanie traktatu granicznego oraz traktatu o dobrym sąsiedztwie i przyjaznej współpracy, który przyrównywany był do Traktatu Elizejskiego. Symbolicznym początkiem tej fazy była msza pojednania odprawiona w Krzyżowej podczas wizyty kanclerza Kohla w Polsce w 1989 roku, a swoistym mottem i dewizą tego okresu stało się sformułowane w lutym 1990 roku przez Krzysztofa Skubiszewskiego pojęcie wspomnianej we wstępie „wspólnoty interesów” Polski i Niemiec. Powstało wówczas wiele sieci powiązań politycznych, gospodarczych i społecznych. Zaczęto przezwyciężać stereotypy i uprzedzenia narosłe po obu stronach przez ponad czterdzieści lat od zakończenia wojny.

W polityce Niemiec wobec Polski od czasu podpisania traktatów w 1990 i 1991 roku chadecy, głównie Helmut Kohl, a także przedstawiciele innych partii, podkreślali odpowiedzialność Niemiec za nasz kraj wynikającą z bolesnej przeszłości. Rolę Niemiec upatrywano i określano jako „adwokata Polski w Europie". Istotnie kanclerz Kohl działał aktywnie przede wszystkim na forum UE, popierając otwarcie się tego ugrupowania integracyjnego na państwa Europy Środkowo-Wschodniej, które podpisały układy stowarzyszeniowe. Szczególnie widoczny był ten lobbing podczas niemieckiej prezydencji w UE w 1994 roku.

18 H.A. Jacobsen, U podstaw polsko-niemieckiej wspólnoty interesów, [w:] Ze soba czy przeciw sobie. Polska-Niemcy 1989-1992, A. Hajnicz (red.), Warszawa 1996, s. 20.

19 A. Wolff-Powęska, Polska-Niemcy: dialog w nauce i polityce, „Przegląd Zachodni” 2004, nr 2, s. 4. 
Drugim ważnym elementem polityki Niemiec wobec RP były działania na rzecz wsparcia procesu transformacji, modernizacji i rozwoju gospodarczego naszego państwa, wyrażające się w restrukturyzacji i częściowym umorzeniu polskiego zadłużenia wobec RFN oraz w znacznym rozszerzeniu i wzbogaceniu współpracy gospodarczej (dynamizacji handlu, lokowaniu w Polsce inwestycji bezpośrednich, pomocy kredytowej itp.).

Ważnym dla Polski aspektem stosunków z Niemcami było w omawianym okresie podjęcie rokowań w sprawie wypłaty odszkodowań dla polskich ofiar III Rzeszy (w tym głównie dla byłych więźniów niemieckich obozów koncentracyjnych i robotników przymusowych). Kwestia ta nie została uregulowana w traktacie o dobrym sąsiedztwie ${ }^{20}$. Pod koniec 1991 roku utworzona została Fundacja Polsko-Niemieckie Pojednanie, która dysponowała funduszem w wysokości 500 mln DEM. Jednak kwoty wypłaconych odszkodowań nie satysfakcjonowały ofiar ${ }^{21}$, a dodatkowo wiele $\mathrm{z}$ nich nie zostało objętych tymi świadczeniami.

Jednym z zadań w polityce zagranicznej Niemiec realizowanym wobec Polski było wspieranie mniejszości niemieckiej, w tym udzielanie wsparcia finansowego $\mathrm{z}$ budżetu federalnego na nauczanie języka niemieckiego, zachowanie, pielęgnowanie i rozwój niemieckiego dziedzictwa kulturowego, a także na inne przedsięwzięcia podnoszące standard życia mniejszości (kanalizacje, wodociągi, infrastruktura w dziedzinie ochrony zdrowia) itp. Do regionów zamieszkanych przez mniejszość delegowano nauczycieli języka niemieckiego. Federalny Urząd Administracyjny wystawiał dowody potwierdzające obywatelstwo niemieckie członków mniejszości. W wielu wystąpieniach (m.in. na forum Bundestagu) politycy domagali się wprowadzenia dwujęzycznych nazw topograficznych na tradycyjnych obszarach zamieszkania mniejszości.

Liczne projekty i programy wspierane przez rząd w Niemczech na początku lat 90. dotyczyły także rozwoju pogranicza polsko-niemieckiego. Ich celem była intensyfikacja współpracy przygranicznej i transgranicznej. W efekcie tych działań na pograniczu zaczęły funkcjonować cztery euroregiony (Nysa, Sprewa-Nysa-Bóbr, Pro Europa Viadrina i Pomerania), które przyczyniły się do znoszenia barier ekonomicznych, kulturowych i psychologicznych

20 Kwestia ta była jednym z najczęściej podnoszonych tematów podczas debaty w sprawie ratyfikacji traktatu o dobrym sąsiedztwie w polskim Sejmie.

21 W wyniku międzyrządowego porozumienia zawartego 16.10.1991 r. odszkodowania wypłacono 1,06 mln osób. Por.: W.M. Góralski, J. Sułek, 25 lat traktatu dobrosąsiedzkiego RP-RFN. Polska i Niemcy w Europie XXI wieku. Razem czy osobno?, Warszawa 2016, s. 31. 
(głównie do przezwyciężania stereotypów), integracji lokalnych społeczności oraz zmniejszenia różnic w rozwoju terenów przylegających do granicy.

$\mathrm{W}$ drugiej połowie lat 90 . formuła pojednania jednak wyczerpała się ${ }^{22}$. Krytycy pozytywnego podejścia do oceny tego okresu twierdzili, że był to czas „kiczu pojednania” lub „biznesu pojednania”, „zamiatania pod dywan problemów" (przede wszystkim tych wynikających z przeszłości) i unikania debaty o kontrowersjach, tzn. o tym, co nadal dzieliło Polaków i Niemców. Konstatowano, że dialog prowadzony z Niemcami w tych latach był powierzchowny, a nad pragmatyczną współpracą dominowały ogólniki, frazesy i „puste gesty”. Wyrazem owej powierzchowności i potwierdzeniem drugorzędnej roli Polski w polityce zagranicznej Niemiec miał być m.in. brak zaproszenia polskiego prezydenta na obchody 50. rocznicy zakończenia II wojny światowej. Faktem potwierdzającym tezę o współkształtowaniu polityki zagranicznej Niemiec przez Niemiecki Parlament Związkowy było zaproszenie ministra spraw zagranicznych, Władysława Bartoszewskiego, do wygłoszenia przemówienia $\mathrm{z}$ okazji półwiecza zakończenia wojny przed połączonymi izbami Bundestagu i Bundesratu.

$\mathrm{Z}$ polskiej strony $\mathrm{w}$ omawianym okresie rzeczywiście nie podnoszono różnic interesów, aby nie niszczyć budowanego na różnych płaszczyznach dialogu i porozumienia.

ad 2/ Lata 1998-2007 to drugi okres, w którym punktem zwrotnym i symbolem przejścia do drugiej fazy była wspomniana powyżej rezolucja Bundestagu z 29 maja 1998 roku pt. „Wypędzeni, przesiedleńcy i mniejszości niemieckie są pomostem między Niemcami i ich wschodnimi sąsiadami”. W tych latach miało dojść w zamyśle rządu RFN do zmiany paradygmatu - miało nastąpić przejście od fazy pojednania do fazy partnerstwa z Polską. Tymczasem nastał okres ochłodzenia stosunków i odejście od deklarowanej wcześniej „wspólnoty interesów". Nastąpiło przejście do uzewnętrzniania sprzeczności i różnic. Okres ten rozpoczął się, jak stwierdzono powyżej, w efekcie przeforsowania przez chadeckich deputowanych (jeszcze w końcowym okresie rządów koalicji CDU/CSU-FDP) rezolucji zawierającej hasła sformułowane przez radykalnych działaczy wywodzących się z kręgów Związku Wypędzonych, które można było odczytać jako próbę konfrontacji z Polskąą. Apele szefowej Związku Wypędzonych pod adresem rządu RFN, aby poparcie dla akcesji

22 M. Mildenberger, Czy „wspólnota interesów” funkcjonuje? Stosunki polsko-niemieckie w latach 1989-2005, [w:] Stosunki polsko-niemieckie 1949-2005. Wspólnota wartości i interesów?, B. Kerski, W.D. Eberwein (red.), Olsztyn 2005, s. 172.

23 Tamże, s. 170-171. 
Polski do UE uzależnić od realizacji żądań Związku dotyczących możliwości powrotu w strony rodzinne i wypłaty odszkodowań za pozostawione tam mienie oraz wspomniana powyżej rezolucja, spowodowały ostrą odpowiedź Sejmu RP w formie oświadczenia z 3 lipca 1998 roku, w którym zastrzeżono nienaruszalność polskich granic i polski tytuł własności do nieruchomości na ziemiach zachodnich i północnych ${ }^{24}$.

Po wygranych przez SPD wyborach w 1998 roku kanclerz Gerhard Schröder zapowiedział „więcej realizmu” i uwzględnianie interesów niemieckich w polityce zagranicznej, głównie w polityce europejskiej. Ogólnie jednak w odniesieniu do rządów koalicji SPD-Zieloni można skonstatować, że mimo obaw formułowanych w Polsce, rząd G. Schrödera kontynuował politykę poparcia dla Polski na forum UE, nie zapominając jednakże o niemieckim interesie narodowym. W obliczu obaw zgłaszanych przez społeczeństwo niemieckie, RFN wynegocjowała okres przejściowy (do 1 maja 2011 roku) dotyczący otwarcia rynku pracy dla pracowników z Polski. Polska z kolei, wsłuchując się w lęki swego społeczeństwa, uzyskała okres przejściowy m.in. dotyczący swobody przepływu kapitału (chodziło o ograniczenie możliwości zakupu ziemi).

Wejście Polski do Unii Europejskiej miało przyczynić się, zgodnie z oczekiwaniami, do większego równouprawnienia, likwidacji (a przynajmniej zmniejszenia asymetrii) i autentycznego odprężenia we wzajemnych relacjach. Spodziewano się odhistoryzowania stosunków, strategicznego partnerstwa i zacieśnienia współpracy. Tymczasem zadrażnienia trwały, a wpływ historii na współczesne stosunki był nadal ogromny. Wraz z 2004 rokiem zakończyła się rola Niemiec jako adwokata i pośrednika na drodze Polski i innych państw Europy Środkowo-Wschodniej do struktur euroatlantyckich.

Podczas obchodów „Dnia Ojczyzny” 3 września 2000 roku kanclerz G. Schröder oświadczył, że Niemcy nie mają roszczeń terytorialnych wobec swoich sąsiadów i że „rząd federalny nie zamierza obciążać stosunków z tymi państwami poprzez polityczne i prawne kwestie, pochodzące z przeszłości”25. Z kolei w kontekście narastających żądań odszkodowawczych wysuwanych

24 Oświadczenie Sejmu Rzeczypospolitej Polskiej z dnia 3 lipca 1998 r. w sprawie rezolucji Bundestagu „Wypędzeni, przesiedleńcy i mniejszości niemieckie są pomostem między Niemcami i ich wschodnimi sąsiadami” z dnia 29 maja 1998 r., M.P. z 1998 r. nr 23, poz. 332.

25 G. Schröder, Rede von Bundeskanzler Gerhard Schröder anlässlich des 50. Jahrestages der Charta der deutschen Heimatvertriebenen am Tag der Heimat am Sonntag, 3. September 2000 in Berlin, http://adrien.barbaresi.eu/corpora/speeches/BR/t/152.html (dostęp: 19.04.2016). 
wobec Polski przez Powiernictwo Pruskie kanclerz w przemówieniu wygłoszonym w Warszawie z okazji 60. rocznicy wybuchu Powstania Warszawskiego zapowiedział, że rząd federalny nie będzie wspierał roszczeń restytucyjnych płynących z Niemiec.

W omawianym okresie kontynuowane były też negocjacje i zapadały uzgodnienia dotyczące odszkodowań dla ofiar niemieckich obozów koncentracyjnych i polskich robotników przymusowych z czasów II wojny światowej. Wypłata odszkodowań (mimo większej puli, nadal w postaci symbolicznych kwot) nie została w Polsce odczytana jako element budowy zaufania, lecz jako chęć uwolnienia się przez Niemcy od historycznej odpowiedzialności za wyzysk i ucisk w czasie wojny. Fundacja Polsko-Niemieckie Pojednanie wypłaciła w latach 2001-2006 ponad 483 tys. osób świadczenia opiewające na ok. 1 mld EUR ${ }^{26}$. Łącznie ofiary III Rzeszy otrzymały wypłaty w wysokości ok. 5 mld PLN.

Problemem, który w szczególny sposób zakłócił atmosferę wzajemnych relacji była koncepcja Związku Wypędzonych zbudowania w Berlinie Centrum przeciw Wypędzeniom. Początkowo kanclerz G. Schröder odmówił poparcia dla Centrum. Później jednak stosunek rządu uległ zmianie i debata toczyła się już nie o to „czy”, ale wyłącznie na temat formuły przedsięwzięcia, czyli: jakie ma to być Centrum? Socjaldemokraci lobbowali na rzecz utworzenia „europejskiego” Centrum przeciw Wypędzeniom, odrzucając niemieckocentryczną perspektywę. Strona polska była jednoznacznie krytycznie ustosunkowana do tego projektu. Wyrazem kulminacji procesu pogarszania stosunków między Niemcami i Polską było przyjęcie przez Sejm RP rezolucji z 10 września 2004 roku, w której wezwano rząd RP do zażądania od Niemiec reparacji za szkody wyrządzone naszemu państwu i narodowi podczas okupacji.

$\mathrm{Na}$ wzajemnych stosunkach $\mathrm{w}$ omawianym okresie cieniem położyły się także przeciwstawne stanowiska obu rządów na temat udziału w wojnie w Iraku oraz zapisów Konstytucji Europejskiej odnoszących się do podziału głosów w Radzie. Różniły się one bowiem od korzystnych dla naszego kraju rozwiązań zawartych w traktacie nicejskim (wynegocjowanych notabene dzięki lobbingowi na rzecz naszego państwa ze strony Niemiec), a ich efektem miało być zmniejszenie wpływu Polski na wynik głosowań w tym gremium.

Lata 2005-2007 (okres „niechętnej obojętności” - określenie Krzysztofa Ruchniewicza) przyniosły wraz ze zmianą rządów w Polsce i w Niemczech dalsze oziębienie stosunków. Prezydent Lech Kaczyński oraz premier

26 W.M. Góralski, J. Sułek, dz. cyt., s. 32. 
Jarosław Kaczyński odnosili się do Niemiec z dystansem, a ówczesna minister spraw zagranicznych, Anna Fotyga, domagała się renegocjacji traktatu, aby m.in. poprawić sytuację Polonii w Niemczech. Ochłodzenie stosunków i spadek wzajemnego zaufania unaoczniły różnice interesów i problemy, które w poprzedniej fazie były przemilczane i pomijane. Cieniem na wzajemnych stosunkach położyła się także kwestia umowy dotyczącej budowy gazociągu Nord Stream, podpisanej we wrześniu 2005 roku.

Kolejnym elementem polityki Niemiec - odebranym negatywnie przez polski rząd - były naciski w sprawie przyjęcia pakietu klimatycznego dotyczącego: zróżnicowania źródeł energii, redukcji emisji gazów cieplarnianych (a więc zmniejszenia produkcji energii z węgla) i zwiększenia udziału energii pochodzącej ze źródeł odnawialnych.

Podsumowując ten okres można stwierdzić, że formuła „wspólnoty interesów” została zastąpiona formułą „wspólnoty konfliktów” albo „wspólnoty sprzecznych interesów".

ad 3/ Lata 2007-2015 to faza poprawności i dążenia do dojrzałego partnerstwa. Zwycięstwo Platformy Obywatelskiej w wyborach z 2007 roku przyjęto w RFN jako zapowiedź poprawy stosunków i podniesienia współpracy na wyższy poziom. Rzeczywiście tak się też stało. Kwestie sporne ponownie odeszły na plan dalszy. Podkreślano głównie dążenie do partnerstwa i współpracy obu państw przede wszystkim na forum Unii Europejskiej. Partia PiS, pozostająca w opozycji, krytykowała politykę Polski wobec Niemiec jako politykę uległości, prowadzoną „na kolanach”.

Mimo istnienia różnic (np. ograniczone poparcie - zdecydowanie poniżej oczekiwań Polski - uzyskała ze strony Niemiec zgłoszona przez Polskę inicjatywa Partnerstwa Wschodniego) współpraca i współdziałanie obu państw uległo w porównaniu do okresu poprzedniego znacznej intensyfikacji.

Największe zbliżenie $\mathrm{w}$ stosunkach polsko-niemieckich $\mathrm{w}$ omawianym okresie miało miejsce w 2011 roku. Znalazło ono m.in. odzwierciedlenie we Wspólnym oświadczeniu i obejmującym ponad 90 punktów Programie współpracy, jakie przyjęte zostały w czerwcu 2011 roku przez rządy obu krajów podczas obchodów 20. rocznicy podpisania traktatu o dobrym sąsiedztwie i przyjaznej współpracy. Trzecim ważnym dokumentem w tymże roku była rezolucja Bundestagu pt. „Niemcy i Polska - odpowiedzialność wynikająca z historii, przyszłość w Europie ${ }^{27}$ " przegłosowana także z okazji

27 Deutscher Bundestag, Drucksache 17/6145 vom 9.06.2011, Antrag der Fraktionen CDU/CSU, SPD, FDP und Bündnis 90/Die Grünen: Deutschland und Polen - Verantwortung aus der Geschichte, Zukunft in Europa. 
tego jubileuszu. Kolejny dokument z 12 czerwca 2011 roku stanowiło Wspólne Oświadczenie Okrągłego Stołu w sprawie wspierania niemieckiej mniejszości w Polsce i obywateli niemieckich polskiego pochodzenia i Polaków w Niemczech, przyjęte $\mathrm{w}$ wyniku przeprowadzonych rozmów przedstawicieli polskiego i niemieckiego Ministerstwa Spraw Wewnętrznych oraz reprezentantów mniejszości niemieckiej i Polonii w RFN. Wymieniono w nim enumeratywnie działania, jakie powinny zostać podjęte w celu pełnej realizacji zapisów art. 20-22 traktatu o dobrym sąsiedztwie.

W polityce Niemiec wobec Polski po 2007 roku ogromną rolę odegrały uwarunkowania zewnętrzne (międzynarodowe), do których zaliczyć należy przede wszystkim kryzys ekonomiczny i finansowy oraz jego skutki uzewnętrznione głównie w państwach strefy euro. Republika Federalna Niemiec stała się głównym aktorem w Unii Europejskiej działającym aktywnie na rzecz stabilizacji sytuacji w państwach eurogrupy (przede wszystkim Grecji) i samej waluty euro. To Niemcy przeforsowały projekt Europejskiego Mechanizmu Stabilizacyjnego oraz Paktu Stabilności. Polska wspierała te przedsięwzięcia.

Drugą ważną determinantą stosunków polsko-niemieckich stał się konflikt rosyjsko-ukraiński. Polska starała się pełnić w stosunku do Ukrainy rolę podobną do tej, jaką pełniły wobec niej Niemcy w procesie akcesji do UE. Poparcie ze strony Niemiec dla stowarzyszenia, a następnie członkostwa Ukrainy w Unii było znacznie mniejsze. RFN zachowywała większą wstrzemięźliwość, nie chcąc narażać na szwank swych relacji z Rosją. W pierwszej fazie konfliktu rosyjsko-ukraińskiego widoczne było współdziałanie ministrów spraw zagranicznych Polski i Niemiec (a także Francji) w procesie jego rozwiązywania. Później, wraz z powstaniem tzw. grupy normandzkiej, Polska została z niego wyeliminowana.

Trzecim czynnikiem zewnętrznym, który spowodował największe kontrowersje i pogorszenie wzajemnych relacji, był kryzys migracyjny. Niemcy przyjęły w 2015 roku około miliona uchodźców i zażądały od pozostałych krajów członkowskich UE solidarnej pomocy w ich integracji, a przede wszystkim zgody na przyjęcie określonych grup migrantów. Polska wyraziła sprzeciw wobec przyjmowania ludzi innych religii i kultur oraz wyznających odmienny system wartości, co stało się powodem ostrej krytyki skierowanej przeciwko naszemu państwu.

Nowy akcent $\mathrm{w}$ stosunkach polsko-niemieckich w omawianym okresie stanowiło oficjalne podniesienie na płaszczyźnie rządowej kwestii statusu i praw Polonii w Niemczech. Zapoczątkowała to nota, aide-memoire, przekazana po zakończeniu oficjalnych rozmów w grudniu 2009 roku niemieckiemu MSZ przez polskiego ministra spraw zagranicznych Radosława Sikorskiego. 
Stwierdzono w niej, że przynajmniej niektórzy spośród członków Polonii (potomkowie dawnych migrantów) ${ }^{28}$ powinni być uznani za mniejszość narodową w Niemczech. Podkreślono, że tezie o istnieniu takiej mniejszości nie można odmówić racjonalnego uzasadnienia. W efekcie od 2010 roku trwały wspomniane powyżej rozmowy okrągłego stołu, a ich ukoronowaniem było Wspólne Oświadczenie z 12 czerwca 2011 roku, w którym Niemcy zobowiązały się do utworzenia i finansowania biura kontaktowego Polonii w Berlinie oraz Centrum Dokumentacji Kultury i Historii Polaków w Niemczech z siedzibą w Domu Związku Polaków w Bochum. Oprócz tego strona niemiecka zapowiedziała upamiętnienie ofiar Związku Polaków w Niemczech prześladowanych i zamordowanych w czasie II wojny światowej, co nastąpiło w rezolucji przyjętej przez Bundestag 10 czerwca 2011 roku z okazji 20-lecia traktatu o dobrym sąsiedztwie.

\section{$* * *$}

Prezydent Bronisław Komorowski, przemawiając w Bundestagu 10 września 2014 roku z okazji 75. rocznicy wybuchu II wojny światowej podkreślił, że Polska i Niemcy przeszły drogę od wrogości „do pojednania i odbudowy poczucia wzajemnej bliskości i zdolności do współpracy". W minionym ćwierćwieczu stworzona została bogata infrastruktura wzajemnych kontaktów (politycznych, gospodarczych, naukowych, kulturalnych, społecznych). Frank-Walter Steinmeier podczas wizyty w Polsce 19 kwietnia 2016 roku podkreślał, że ważne jest, by te mosty, które już zostały zbudowane między Polską a Niemcami, utrzymać. Z kolei przewodniczący Bundestagu Norbert Lammert stwierdził, że minione ćwierćwiecze było najlepszym okresem w tysiącletniej historii naszych kontaktów ${ }^{29}$.

Niestety obecnie stosunki między Polską a Niemcami znajdują się ponownie w fazie ochłodzenia. Wizyta premier Beaty Szydło w RFN w lutym 2016 roku w opinii korespondenta dziennika „FAZ” potwierdziła, a nie zdementowała "rozdźwięk” pomiędzy obydwoma państwami. Analitycy ostrzegają przed niebezpieczeństwem narastania nieporozumień w relacjach polsko-niemieckich (szczególnie po decyzji Brytyjczyków o wyjściu z UE).

28 Zdaniem Polski, potomkowie Polaków z Zagłębia Ruhry, którzy osiedlili się w Niemczech już w XIX wieku, spełniają jednoznacznie kryteria zasiedziałej mniejszości narodowej.

29 B.T. Wieliński, Polska jest dla nas kluczowym krajem, „Gazeta Wyborcza”, 16.06.2016, s. 12. 
Chodzi tu szczególnie o różnice poglądów na temat przyszłego kształtu Unii Europejskiej i pogłębiania procesu integracji.

Odpowiadając na pytanie, czy Polska w minionym ćwierćwieczu była partnerem drugiej kategorii, stwierdzić należy, że nie zajmowała w polityce zagranicznej Niemiec takiej pozycji, jak Francja czy Wielka Brytania. Z pewnością jednak wśród państw Europy Środkowo-Wschodniej była najważniejszym partnerem. Norbert Lammert określa pozycję Polski w polityce zagranicznej Niemiec jako „kluczowego kraju jeśli chodzi o zrastanie się Europy na Wschodzie"30.

Podsumowując efekty 25 lat stosunków polsko-niemieckich stwierdzić należy, że bilans współpracy jest w przeważającej mierze pozytywny. Oto wybrane jego aspekty:

- wymiana gospodarcza rozwijała się dynamicznie z korzyścią dla obu stron (w 2015 roku udział Niemiec w polskim eksporcie ogółem przekroczył poziom 27\%, a Polska osiągnęła w handlu $z$ Niemcami dodatnie saldo. Pod względem liczby i wartości bezpośrednich inwestycji zagranicznych w Polsce przedsiębiorstwa niemieckie zajmują pierwsze miejsce);

- współpracę kulturalną i wymianę młodzieży także określić można mianem sukcesu;

- współpraca przygraniczna i transgraniczna pozwoliła zapomnieć o czasach, gdy granica stanowiła barierę trudną do przebycia;

- opracowano pierwszy tom wspólnego podręcznika do nauczania historii. Jeśli chodzi o listę podnoszonych problemów, to pozostaje ona także długa. Należy jednak wyrazić nadzieję, że wspólne obchody jubileuszu 25-lecia traktatu oraz przeprowadzone konsultacje międzyrządowe pomogą zażegnać obecny impas.

\section{Zusammenfassung}

Im Artikel wird die Politik Deutschlands gegenüber Polen seit der Unterzeichnung des Vertrages über gute Nachbarschaft und freundschaftliche Zusammenarbeit am 17. Juni 1991 bis heute dargestellt. Der Vertrag markierte die historische Wende in den vielschichtigen deutsch-polnischen Beziehungen und eröffnete ein neues Kapitel. Man sprach damals von der Werte- und Interessengemeinschaft. Später aber war auch die Rede von einer Konflikt- und Streitgemeinschaft. Deswegen wurden die vergangenen 25 Jahre auf Grund von Konsens und Dissens in den Beziehungen sowie aus

30 Tamże. 
dem Gesichtspunkt ihrer Wahrnehmungsunterschiede in drei Perioden unterteilt: 1990 bis 1998: Phase der Verständigung und Versöhung; 1998 bis 2007: Phase der Distanz in den Beziehungen; 2007 bis 2015: Phase der Suche nach erwachsener Partnerschaft.

Die Bilanz der Errungenschaften in der Zusammenarbeit zwischen Deutschland und Polen fällt im vergangenen Vierteljahrhundert im allgemmeinen positiv aus. Es ist vor allem das Agieren von Deutschland als Anwalt Polens in der EU und NATO hervorzuheben. Die Herausforderungen, die auch Konfliktfeldern zwischen Polen und Deutschland markieren, betreffen unter anderem folgende Themen: polnische Minderheit in Deutschland, Flüchtlingskrise, das Verhältnis zu Russland und zur Ukraine, Energiepolitik, Europapolitik und Geschichtspolitik.

\section{Bibliografia}

BINGEN D., 25 Jahre deutsch-polnische Partnerschaft. Politische Freundschaft auf Bewährung, „Polen - Analysen”, nr 180, 19.04.2016.

CICHOCKI M.A. i in., Wspólnota sprzecznych interesów? Polska i Niemcy w procesie rozszerzania Unii Europejskiej na Wschód, Warszawa 1999.

DEUTSCHER Bundestag, Drucksache 13/108845 vom 27.05.1998, Antrag der Fraktionen der CDU/CSU und FDP: Vertriebene, Aussiedler und deutsche Minderheiten sind eine Brücke zwischen den Deutschen und ihren östlichen Nachbarn.

DEUTSCHER Bundestag, Drucksache 17/6145 vom 9.06.2011, Antrag der Fraktionen CDU/CSU, SPD, FDP und Bündnis 90/Die Grünen: Deutschland und Polen - Verantwortung aus der Geschichte, Zukunft in Europa.

DEUTSCHER Bundestag, Drucksache 18/8861 vom 21.06.2016, Antrag der Fraktionen der CDU/CSU und SPD: Versöhnung, Partnerschaft, Zusammenarbeit - 25 Jahre deutsch-polnischer Vertrag über gute Nachbarschaft und freundschaftliche Zusammenarbeit.

EBERWEIN W.D., ECKER_EHRHARDT M., Deutschland und Polen. Eine Werte- und Interessengemeinschaft? Die Eliten-Perspektive, Opladen 2001.

HAJNICZ A. (red.), Ze soba czy przeciw sobie. Polska-Niemcy 1989-1992, Warszawa 1996.

KERSKI B., EBERWEIN W.D. (red.), Stosunki polsko-niemieckie 1949-2005. Wspólnota wartości i interesów?, Olsztyn 2005.

ŁADA A., Barometr Polska-Niemcy 2016. Polacy i Niemcy o sobie nawzajem 25 lat po podpisaniu traktatu o dobrym sąsiedztwie i przyjaznej wspótpracy, Warszawa 2016. 
RUCHNIEWICZ K., Stosunki na rozdrożu, „przez granice”, „Kurier Szczeciński” dod. „SGP Euroregionu Pomerania” 2016, nr 1.

STOLARCZYK M., Zbieżność i różnice interesów w stosunkach polsko-niemieckich w latach 1989-2009, Katowice, 2010.

WOLFF-POWĘSKA A., Polska - Niemcy: dialog w nauce i polityce, „Przegląd Zachodni" 2004, nr 2.

akademia.krzyzowa.org.pl

www.dw.com

www.stosunki.pl

www.wochenblatt.de 